\title{
How China Improves Global Governance capability —-Take the field theory as the visual threshold
}

\section{Qi Tan}

Nankai University, Tianjin 300000, China

\begin{abstract}
The world is currently experiencing a trend of power shifting from east to west. The raging epidemic and the continuous development of deglobalization have made the world more uncertain. The world's original governance rules are not enough to solve real problems, and China urgently needs to improve its global governance capability.
\end{abstract}

Key words: Global Governance capability; Field theory

Publication date: April, 2021; Publication online: 30 April, 2021

*Corresponding author: Qi Tan, steventanqi@163.com

\section{Introduction}

Field theory is one of the important theories of sociology. It helps to break away from the limitation of a single national agent when studying international relations. In this essay, in the first section, I will introduce the "field theory" logic of global governance hegemony in the section. Next, I want to discuss how China can enhance capability of global governance.

\section{2 “Field Theory" Logic of Global Governance}

\section{Hegemony}

Field theory is one of the main theories of sociology. It is a conceptual model of human behavior. It originated from the concept of physics in the mid-19th century. The proposer is Kurt Kofka. Generally speaking, it means that every action of a person is affected by the field in which the action occurs, and the field does not refer to the physical environment alone, but also includes the behavior of others and many factors connected to it. Bourdieu, a master of sociology with world influence, inherited and developed the concept of field, and became a master of field theory. Bourdieu believes that the field is jointly constructed by members of society in accordance with specific logical requirements. It is the main place for social individuals to participate in social activities. It is a place for concentrated symbolic competition and individual strategies. The purpose of this competition and strategy is to produce valuable symbolic commodities, and the value of symbolic commodities depends on the classification of it by the relevant consumer society. The victory of symbolic competition means that a symbolic commodity is judged to have more value than its competitors and can be imposed it on society, Bourdieu calls it "symbolic violence".

In addition, the field theory puts forward the importance of "habitus", which is a fundamental generalization of the behavioral logic of the field. In short, all activities of the actor in the field are habitual behaviors. Habitus is manifested in practice as a pre-rational, non-inference "sense of practice", that is, when facing a brand-new practical task, the behavior experience first calls the cognitive schema for comparison without thinking, and selects the most suitable for the present situation. The historical experience of the situation is used as a reference to formulate an action plan. The whole process is similar to self-perception in a stress-response model, without feasibility demonstration. (Pierre Bourdieu, 1992) The basis of habituation is the rules of the field. The formation of habituation is the process of actor cognition, acquisition, internalization and practice of field rules. At the beginning of the creation of a field, an institutional system must be established first, including the definition of the basic nature, 
functions and goals of the field, the restrictions on the identities and qualifications of field participants, the setting of the positional relationship of actors in the field, and the criteria for field interaction, The determination of the value of field capital, the exchange method of capital and power, various guarantees reward and punishment mechanisms. (Chandra Mukerji. 2014)

Capital is the driving force of field changes, and is an effective power resource in a specific field. "Only in the relationship with a field, a capital can exist and play a role" (budie, 2007). Capital is not only the goal of competition in field activities, but also a means of competition. Bourdieu divides capital into three types: economic capital, social capital, and cultural capital. Later, Bourdieu continued to perfect the theory and proposed a fourth type of capital, symbolizing capital. Among them, economic capital is the basis of various types of capital, including two core forms of tangible materialization and symbolization, and has the function of payment, exchange, and measurement of other capital values. Social capital is a network relationship resource acquired by an actor in a specific position in the field, which is manifested in the working relationship and organizational relationship with other actors. (Pierre Bourdieu) Cultural capital is the embodiment of field theory's unique cognition of the essence of capital, and refers to cultural resources that can have an impact on field structure, rules and activities. Symbolic capital is intangible assets such as objective evaluation, status, reputation, prestige and credit level accumulated by actors in the field. Although symbolic capital cannot determine the final result of field interaction, nor can it bring direct power gains to actors, it can play an additive effect in the transformation of capital types, enabling actors with more symbolic capital to be able to perform under the same conditions. They will get more benefits.

\subsection{Governance actors}

As the world is becoming increasingly "fragmented" and increasing uncertainty, the transmission of political authority no longer follows hierarchical and chronological order, which has changed the traditional transmission of authority, and is more accidental and sudden. Compared with traditional state governance, the way the field is the governing body is more flexible. The distribution level of this field is intricate and complex. It is a network structure in which authoritative fields compete, cooperate, and govern. The field and the territorial boundaries do not overlap with each other and are superregional. The governance field covers a very wide range. It is no longer limited to sovereign states as the main body. It can be seen from the concept of field. It includes sovereign states, NGOs, multinational companies, social movements, etc., and it is constantly expanding. Among. All kinds of subjects operate independently, but they are connected with each other, and cooperate and participate in governance together. In the field of traditional international relations, the authority between sovereign states is based on regionality, while the concept of field obscures the importance of geographic location to a certain extent, and emphasizes the habit of shaping rules and the importance of capital. Since Western countries have always been in an advantageous position in the international community for a long time, in order to realize common interests, the various governance bodies of these Western countries will also have connections, forming a governance field that is beneficial to Western countries.

\subsection{Governance habitus}

The basis of habituation is field rules, and field rules are more embodied in the rules of international order and international society. Habitus plays a very important role in global governance. As large countries occupy a better position in the international community, they can play a role of demonstration and leadership through their authority in the field, and play a leading role for the members of the field. Fragmented, diversified governance of global issues provides action plans and basic guidelines for reference. Actively shaping governance habits requires a large amount of capital investment and the support of field rules, so the dominant country has more advantages. The path of shaping is often from a historical perspective. The dominant country combines its own cognition and experience to propose a set of governance methods that include its beliefs and theoretical concepts, so that It can be implemented in field interaction until it becomes a governance habit widely recognized by the international community.

\subsection{Governance capital}

The essence of field interaction is the exchange and circulation of different types of capital. By continuously changing the form of power resources in the position occupied by the actors, they make them into higher-value capitals, and enhance their position in the field to strive for more capital trading opportunities, and then gain more power. Symbolic capital is derived from the country's practical experience in solving different types of global problems, such as the country's initiatives in solving financial global 
governance, climate issues, and inspiring suggestions in the formulation of international rules, etc. It promotes the promotion of its discourse status and prestige, thereby enhancing the country's governance capital. Social capital mainly establishes the mode of exchanges between countries, such as proposing cooperation initiatives, developing international mechanisms, and establishing international organizations. (Richard H. Friman, 2015) In this way, major countries and their localities can enhance their authority and rationality in the international community, and enhance their social capital. The accumulation of cultural capital is a process in which a country uses its international discourse power to transform its own ideas and discourse into public cultural products, and promotes different countries to be subtly induced in cultural consumption and tasting. Compared with simple and straightforward missions, cultural products have diverse forms and subtle expressions, making it easier to achieve large-scale dissemination and penetration of ideas.

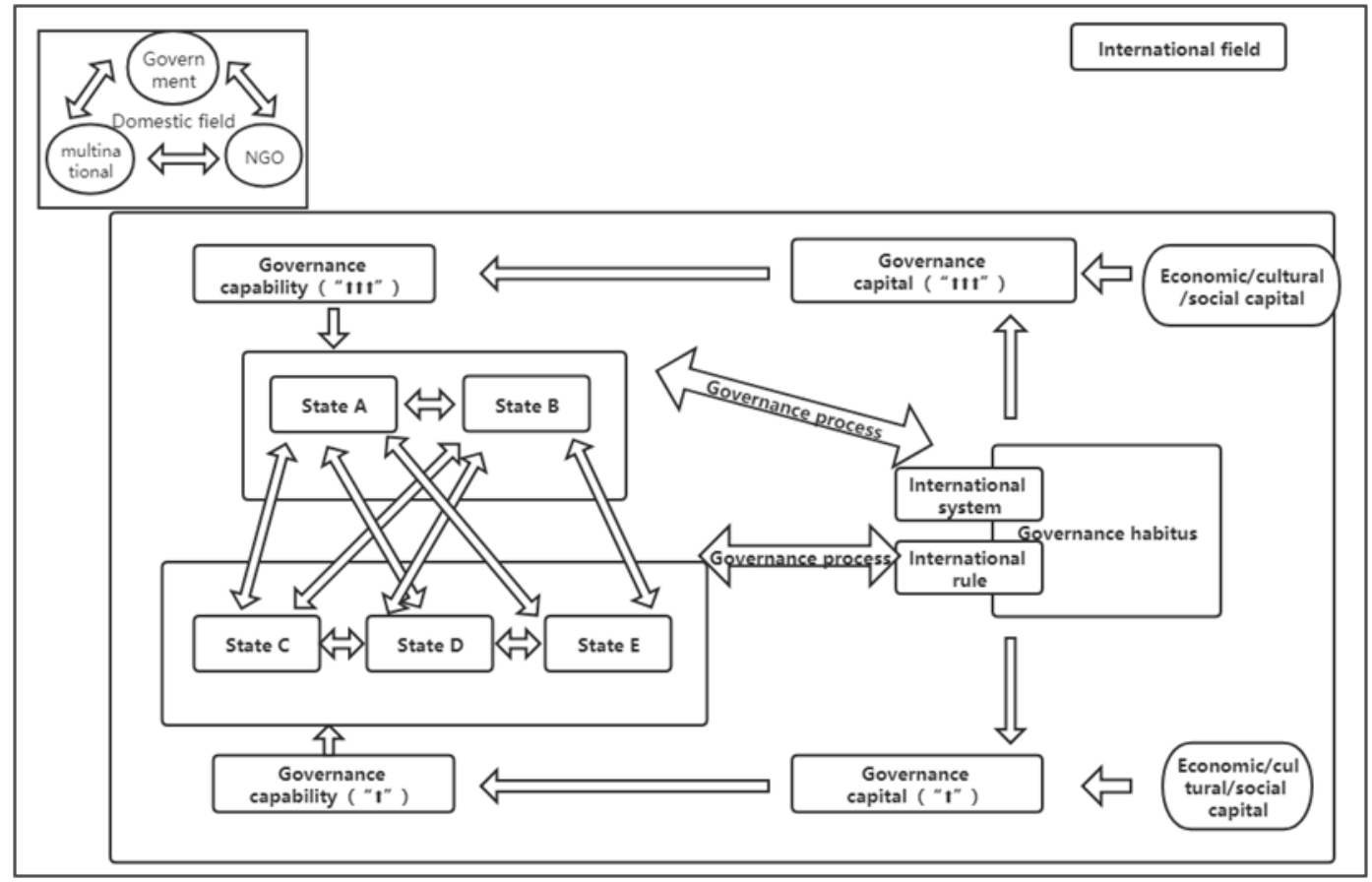

Note: "+" means a relatively low growth rate, and "+++" means a relatively high growth rate; There is a domestic field in the country itself. In the process of global governance, the strong countries are interconnected to form a field of strong countries, while weak countries have also formed a certain field in order to realize their own interests. The two fields compete for governance capital and governance power in the process of communication and contact. In the process of forming governance habits, due to the advantages of powerful countries, they can mobilize resources more widely and use their historical legitimacy. Therefore, it has higher governance capital and thus stronger governance power. An example of this process has developed to a certain degree is the governance hegemony of the United States.

\section{How China enhances capability of global}

\section{governance}

\subsection{Enhancing the participation of domestic field governance entities}

At present, the number of non-governmental organizations participating in global governance in our country is small, and the level of participation is also low, and they have not been able to play their due role. Take the UN Economic and Social Council as an example. Among the 5163 NGOs currently in consultative status, only 82 are from China (including Hong
Kong and Macau), while there are 1,680 in the United States, 366 in the United Kingdom, and 348 in India.(Wang,yaohui, 2018)This is not commensurate with China's international status, and is not conducive to China's full participation in global governance. With the deepening of globalization, the destiny of all countries in the world is more closely related. Many global issues such as climate change, terrorism, and refugee flows urgently need to strengthen global governance. Different types of governance entities negotiate and cooperate together and use their respective advantages to solve global problems, which has become an important feature of global 
governance. Compared with government organizations, NGOs have many advantages in participating in global governance. On the one hand, NGOs pay attention to global issues from the perspective of all mankind, and have gathered a group of professionals in related fields, and they are close to the grassroots. This can enable NGOs to raise many important global issues that are not widely recognized, and provide first-hand information and professional advice for solving these issues. On the other hand, due to the independence, non-governmental nature, and flexibility of NGOs, it is easier to gain the trust of the governments and the public of other countries, thus establishing communication channels. In addition, promoting the participation of nongovernmental organizations in global governance will also help cultivate the international awareness of domestic people's concern about the destiny of mankind and dispel narrow extreme nationalism.

Therefore, an important factor in improving China's governance capabilities is to fully mobilize the enthusiasm of various governance entities in the domestic governance field so that they can effectively and fully participate in global governance. First, it is necessary to create an atmosphere that encourages and supports domestic NGOs to participate in global governance. At present, the Chinese people's understanding and support for China's overseas aid activities are not enough. The establishment of the National Agency for International Development Cooperation at the beginning of this year is an opportunity to reasonably incorporate the power of non-governmental organizations into the international development cooperation system, thereby enhancing the public's awareness of participating in international affairs, Cultivate the mentality of a powerful country and attract relevant talents. At the same time, it is necessary to coordinate the relationship between the government, enterprises, and non-governmental organizations, introduce relevant regulations as soon as possible, and form an effective cooperation mechanism. Attention should be paid to maintaining the independence of NGOs, but also to ensure that NGOs' participation in global governance is coordinated with the country's foreign policy to achieve sustainable development.

Secondly, domestic NGOs should improve their own capacity building and increase the level of participation. Needless to say, the level of internationalization of many domestic NGOs is low, and it is difficult to meet the requirements for participating in global affairs. Many foreign
NGOs often submit statements and consultations to relevant countries and international organizations, attend meetings, lobby, and hold presentations. , Published reports and other forms to exert influence and attract international public opinion. In this regard, domestic NGOs should strengthen their learning from foreign NGOs, and learn how to set up and influence global issues.

\subsection{Improve the ability to shape field habitus}

In recent years, China has continued to explore, through the reform of the existing international system and the establishment of various new international systems, to create an institutional field habit that has the characteristics of Chinese practice, can reflect the characteristics of Chinese roads, and has Chinese wisdom and Chinese solutions. It provides a new path to break the global governance hegemony of Western countries and build a fair and reasonable global governance order. In the existing international system, the G20 (Group of Twenty) is an important embodiment of China's promotion of the reform of the existing international economic system. As an important forum for cooperation between developed countries and emerging market countries and developing countries, G20 has a pivotal influence in leading and promoting international economic cooperation. As the world's second-largest economy and a bridge between developing and developed countries, China actively promotes and continuously improves the G20 mechanism. At the G20 Hangzhou Summit, China introduced green finance issues into the agenda for the first time and created a green finance research group; at the same time, China restarted the international financial architecture working group to promote the establishment of a more stable and resilient international financial architecture. In addition, China has also actively carried out G20 peripheral dialogues and maintained communication with international organizations such as the United Nations, ASEAN, and the African Union.

In addition, the new international public products provided by China, especially infrastructure public products and regional or inter-regional public products, have further enriched the means and connotations of global governance, provided Chinese solutions to global problems, and contributed to Chinese power. . From the perspective of system construction, China's establishment of new systems such as the Asian Infrastructure Investment Bank will help promote the participation of developing countries in the global governance process. At the same time, China's 
contribution to the new international system such as the Asian Infrastructure Investment Bank also helps to make up for the inability of the U.S. and Japanese economies to fully provide infrastructure and other public goods due to their decline in power. China's system construction in the global economy has laid a solid organizational foundation for enhancing China's governance capabilities and shaping governance habits.

\subsection{Enhance China's governance capital in field competition, focusing on discourse capital}

In view of China's current dilemma in the promotion of international discourse power, we can consider opening up a new discourse field, mastering discourse initiative by restructuring field rules and relationship networks, and fully releasing the power efficiency of Chinese discourse. "Dialogue of Civilizations in Asia", as an active attempt to create a field, has important enlightening significance: Replacing the field rules of civilization conflicts with mutual learning among civilizations is conducive to improving China's ability to lead and shape habituation, create an equal and beneficial public opinion and institutional context, and provide legitimacy and moral support for Chinese discourse; Replacing the hierarchical relationship structure with the concept of partnership and a community of shared destiny, and taking civilized consensus as the basis for enhancing mutual trust is conducive to giving play to China's unique cultural capital advantages, promoting accurate interpretation and interpretation of Chinese discourse, and promoting the substantial improvement of China's international discourse power.

\section{Conclusion}

All in all, with its strong national strength, the United States has shaped the big power field represented by Western countries and has achieved hegemony in global governance. Under the conditions of the new historical era, the old field of global governance can no longer solve global problems fairly and reasonably. As a representative of emerging countries, China should improve its own field capital and the ability to shape field habits, so as to lead emerging countries to open up new governance fields, so as to better meet the needs of the governance and development.

\section{References}

[1] Rosenau. Along the Domestic-foreign Frontier, 39; Rosenau, Toward an Ontology for Global Governance. In Martin Hew-Son, Timothy J. Sinclair (eds.) [M].
Approach to Global Governance Theory, 295-296.

[2] Julian,Go,Global Fields and Imperial Forms: Field Theory and the British and American Empires,Sociological Theory, Vol. 26, No. 3 (Sep., 2008), pp. 201-229.

[3] Stephen B. Jones, A Unified Field Theory of Political Geography,Annals of the Association of American Geographers, Vol. 44, No. 2 (Jun., 1954), pp.111-123

[4] Pierre Bourdieu, The Logic off Procedure, Translate by Richard Nise, Calif. : STANDFORD UNIVERSITY PRESS, 1992, pp. 52-65.

[5] Chandra Mukerji, "The Cultural Power of Tacit Knowledge: Inarticulacy and Burddieu's Habits", American Journal of Cultural Sociology,Vol.2,No.3,2014,pp.348-375

[6] Bourdieu: "Practical Theory Outline", translated by Gao Zhenhua and Li Siyu, Renmin University of China Press, 2017 edition, p. 310

[7] Pierre Bourdieu, The Logic of Practice, p.16

[8] Bourdieu: "Practical Theory Outline", translated by Gao Zhenhua and Li Siyu, Renmin University of China Press, 2017 edition, p. 289-307

[9] Richard H. Friman, The Politics of Leverage in International Relations: Name, Sandion, Landon: Palgrave Macmillan UK,2015,121-145

[10] Charles Krauthammer, “The Unipolar Moment” , Foreign Affairs, Vol. 70, No. 1, Winter 1990/1991; Charles Krauthammer, “ The Unipolar Moment Revisited”, National Interest, Vol. 70, Winter 2002.

[11] G. John Ikenberry, “Institutions, Strategic Restraint, and the Persistence of American Postwar Order" , International Security, Vol. 23, No. 3, Winter 1998 /1999; G. John Ikenberry, Liberal Leviathan: The Origins, Crisis, and Transformation of the American World Order, Princeton, NJ: Princeton University Press, 2011.

[12] Zbigniew Brzezinski: "The Big Chess Game", Shanghai People's Publishing House, 2007, p. 21.

[13] Zhang Minqian: "US Foreign Economic Strategy", Beijing: World Knowledge Press, 2001, pp. 50-51.

[14] Edward Luck, Mixed Messages: American Politics and International Organization, 1919-1999, Washington: Brooking Institution Press, 1999, p. 16.

[15] Wang,yaohui,Encourage more NGOs to participate in global governance,Beijing Youth Daily,2018 